\title{
The gingival condition of oral contraceptives users at desa Hegarmanah, Kecamatan Jatinangor
}

\author{
Miduk Sibuea, Ina Hendiani, Yanti Rusyanti \\ Department of Periodontics Faculty of Dentistry Universitas Padjadjaran
}

\begin{abstract}
The change of hormonal condition is a systemic condition that affected the periodontium condition. Oral contraceptives is one of the systemic risk that can change hormonal condition. The purpose of the research was to evaluate gingival condition of oral contraceptives users and to find the difference of gingival condition between users and non users of oral contraceptives at Desa Hegarmanah, Kecamatan Jatinangor. The research method was descriptive analytic with purposive sampling, consist of 69 users and 30 non users of oral contraceptives. The gingival condition was scored by using Loe and Sillnes gingival index. The research showed that the average of gingival index in oral contraceptives users was 1.913 and non users was 1.707. The statistic analysis was U Mann Whitney non parametric test and the a was $5 \%$ showed that there was a significant difference of gingival condition between users and non users of oral contraceptives. The conclusion of the research was the gingival condition of oral contraceptives users was different with non users at Desa Hegarmanah Kecamatan Jatinangor but clinically was the same, that is in moderate gingivitis category.
\end{abstract}

Key words: Oral contraceptives, gingival condition.

\section{INTRODUCTION}

Periodontal disease is a disease that affects periodontal tissue, such as gingival, periodontal ligament, cementum and alveolar bone. The most common form of periodontal disease is infection in gingival. This infection is caused by toxin, enzyme or antigen that produced by bacterial plaque invaded the gingival tissue. When a tissue is experincing irritation, it will lead to a defense response to the irritation factor. Response of periodontal tissue to bacterial plaque can be exaggerated if there is an abnormality in systemic condition either pathologically or physiologically. Physiologic condition in human body particularly in women that could cause changes in periodontal tissue response to bacterial plaque is the presence of hormonal changes inside the body specifically estrogen and progesterone. Hormonal changes can also occur in the usage of oral contraception pill or known as KB pill. ${ }^{1-3}$

The main purpose of KB pill is to prevent pregnancy; however, it also can cause various adverse effects either mild or severe and in each individual it doesn't always cause the same symptoms. Commonly adverse effect include vomit, pain in breast, uncontrolled menstruation, facial and gingival hyperpigmentation, edema, gingival bleeding and inflammation. ${ }^{4,5}$ Clinical research has also reported that increased in prevalence of gingival inflammation, lost of periodontium supporting tissue and gingival enlargement in women 
who used oral contraception pill had a higher incidence compare to the one who didn't. $2,6,7$

Until now, it is believed that systemic condition including hormonal changes due to oral contraceptives can be responsible in decreasing periodontal tissue defense, so that it will susceptible to local irritation which is plaque, although didn't cause inflammation directly to gingival. ${ }^{1,8}$ Some research suggest that oral contraceptives does not have adverse effect toward periodontium tissue and does not show any influence in forming plaque accumulation, gingival inflammation or increasing in gingival liquid volume. ${ }^{3,5,9}$ Although there are some debate concerning effect caused by usage of KB pill, this contraception method is hormonal contraception method that still widely used in society other than injection and implant method with the same purpose to make a happy family and also in order to control population growth. ${ }^{10}$

According to WHO, the usage of hormonal contraception increased, of all 380 million couples implemented family planning and 65-75 million among them used hormonal contraception such as oral contraceptives, injection and implant and estimated more than 60 million women around the world used oral contraception. , $^{40,11}$

Desa Hegarmanah is one of village that quite successful in implementing birth control program, which know as KB program. Based on survey data in April 2008 and informal interview with KB Program Field Officer, the percentage of prosperous age family couple that attended KB program were about $80.3 \%$ or 1262 of 1571 family available. Desa Hegarmanah is also near with the location of Faculty of Denstistry Universitas Padjadjaran in Jatinangor so that it strategic to give information and one of UNPAD's caretaker village.

\section{MATERIALS AND METHODS}

The materials and tools used in the study included mouth mirror, probe, tweezers, explorers, flashmild, mask, gloves, informed consent, examination form, questionnaire, cotton and alcohol $70 \%$. The method used was descriptive analytic with purposive sampling. The experiment was conducted on July-Agust 2008.

Plaque examination based on Loe and Sillnes Plaque Index according to Ramfjord Periodontal Disease Index (PDI) on selected teeth, 1.6, 2.1, 2.4, 3.6, 4.1, and 4.4. If one of the teeth was missing, it was substituted by adjacent tooth with the same anatomic structure and in one region.

The criteria of Sillnes and Loe Plaque Index assay were: 0 : no plaque in gingival area; 1 : no plaque visible by unaided eye, but plaque is made visible on the point of the probe after it has been moved across surface at entrance of gingival crevice; 2: Gingival area is covered with a thin to moderately thick layer of plaque, deposit is visible to the naked eye; 3 : moderate accumulation of soft matter, the thickness of which fills out niche produced by gingival margin and tooth surface, interdental area is stuffed with soft debris.

The criteria of Loe and Sillness gingival index assay were in the Table 1 . The formula to account Gingival index was:

Gingival value $/ 1$ tooth $=\underline{\text { Sum of total value per teeth }}$

4

Gingival index/person= Sum of total gum value per teeth

Total teeth examined

The gingivitis severity level was divided into four: (1) normal gum with gingival index of 0 ; (2) mild gingivitis with gingival index $0.1-1.0$; (3) moderate gingivitis with gingival index 1.1-2.0; (4) severe gingivitis with gingival index 2.1-3.0. The hypothesis for gingival condition of users and non users of oral contraceptives at Desa Hegarmanah Kecamatan Jatinangor was tested using $U$ Mann Whitney test.

Table 1. Loe and Silness gingival index.

\begin{tabular}{cll}
\hline Score & Gum condition & Explanation \\
\hline 0 & Normal & Pink and stippling appearance, gummy, tapered interdental papilla \\
1 & Mild gingivitis & Little discoloration and edema, no bleeding when probing \\
2 & Moderate gingivitis & Reddish gingival, edema, and bleeding when probing \\
3 & Severe gingivitis & Dark red appearance, edema, ulceration, and tend to bleed spontaneously \\
\hline
\end{tabular}


The gingival condition of oral contraceptives users at desa Hegarmanah, Kecamatan Jatinangor (Miduk Sibuea et al.)

Table 2. Distribution of users and non users of oral contraceptives at Desa Hegarmanah, Kecamatan Jatinangor.

\begin{tabular}{lcc}
\hline Group & $\begin{array}{c}\text { Total } \\
\text { (n) }\end{array}$ & $\begin{array}{c}\text { Percentage } \\
\text { (\%) }\end{array}$ \\
\hline Users of oral contraceptives & 69 & 69,7 \\
Non users of oral contraceptives & 30 & 30,3 \\
Total & 99 & 100 \\
\hline
\end{tabular}

Table 3. Plaque index average value users and non users of oral contraceptives at Desa Hegarmanah, Kecamatan Jatinangor.

\begin{tabular}{lcc}
\hline Group & $\begin{array}{c}\text { Plaque index } \\
\text { average value }\end{array}$ & Category \\
\hline $\begin{array}{l}\text { Users of oral contraceptives } \\
\text { Non users of oral }\end{array}$ & 1,856 & moderate \\
contraceptives & 1,787 & moderate \\
\hline
\end{tabular}

Table 4. Gingival condition of users and non users of oral contraceptives at Desa Hegarmanah, Kecamatan Jatinangor.

\begin{tabular}{lcccc}
\hline \multirow{2}{*}{ Severity level } & \multicolumn{2}{c}{ Users of oral contraceptives } & \multicolumn{2}{c}{ Non users of oral contraceptives } \\
\cline { 2 - 5 } & Total $(\mathrm{n})$ & Percentage $(\%)$ & Total $(\mathrm{n})$ & Percentage $(\%)$ \\
\hline Mild gingivitis & 0 & 0 & 0 & 0 \\
Moderate gingivitis & 58 & 84.06 & 30 & 100 \\
Severe Gingivitis & 11 & 15.94 & 0 & 0 \\
Total & 69 & 100 & 30 & 100 \\
\hline
\end{tabular}

Table 5. Gingival index average value of users and non users of oral contraceptives at Desa Hegarmanah, Kecamatan Jatinangor.

\begin{tabular}{ccc}
\hline Group & Gingival index average value & Severity level \\
\hline Users of oral contraceptives & 1.913 & Moderate Gingivitis \\
Non users of oral contraceptives & 1.707 & Moderate Gingivitis \\
\hline
\end{tabular}

Table 6. The difference of gingival condition between users and non users of oral contraceptives at Desa Hegarmanah, Kecamatan Jatinangor.

\begin{tabular}{lcccccc}
\hline Group & $\begin{array}{l}\text { Gingival index } \\
\text { average value }\end{array}$ & N & Average of rank & Sum of rank & Value Z & Value P \\
\hline Users of oral contraceptives & 1.923 & 69 & 60.55 & 4178 & 5.507 & 0.000 \\
Non users of oral contraceptives & 1.707 & 30 & 25.73 & 772 & & \\
Total & & 99 & & & \\
\hline
\end{tabular}

\section{RESULTS}

From the results, it was observed that there were two simple groups, users and non users of oral contraceptives at Desa Hegarmanah Kecamatan Jatinangor. Distribution of users and non users of oral contraceptives at Desa Hegarmanah, Kecamatan Jatinangor showed at Table 2.

The oral hygiene level was scored by using Silness and Loe plaque index. The oral hygiene level between users and non users of oral contraceptives at Desa Hegarmanah, Kecamatan Jatinangor was same, that was moderate gingivitis category (Tab. 4).

Gingival condition of users and non users of oral contraceptives at Desa Hegarmanah,
Kecamatan Jatinangor was scored by using Loe and Sillnes. The research showed that there were 11 (15.94\%) severe gingivitis and 58 (84.06\%) moderate gingivitis for users of oral contraceptives, and 30 (100\%) moderate gingivitis for non users of oral contraceptives.

Table 4 shows that the average gingival index of users oral contraceptives at Desa Hegarmanah Kecamatan Jatinangor was 1.913 which was categorized as moderate gingivitis. The gingival index of non users oral contraceptives at Desa Hegarmanah Kecamatan Jatinangor was 1.707, which was categorized as moderate gingivitis.

Table 6 showed the average rank of gingival index for users and the average rank of gingival index for non users oral contraceptives. The statis- 
tic analysis with a was $5 \%$ showed that there was a significant difference gingival condition between users and non users of oral contraceptives.

\section{DISCUSSION}

According to the research, 58 people of the user of oral contraceptives had moderate gingivitis and 11 people had severe gingivitis. All of non users oral contraceptives had moderate gingivitis. Mean gingival index score showed that gingival condition of users was higher than non user oral contraceptives with same oral hygiene level. Oral hygiene level users and non users were similar in moderate category. Mean index plaque of users was 1.856 , and non users was 1.787 and there was not statistically significant difference between plaque index users and non users.

This result suggested that with poor oral hygiene condition confirmed by plaque accumulation it would be followed by the presence of gingival irritation. This result was accordance with Carranza $^{3}$ statement that said there was relationship between poor oral hygiene with gingival index and could be modified by another factor and one of them was hormonal changes. ${ }^{3}$

Based on questionnaire result, users and non users oral contraceptives had similar tooth brushing habit which were three times daily, $55.07 \%$ for users and $53.33 \%$ for non users. Time of tooth brushing were vary. Manson and Eley ${ }^{2}$ concluded that teeth need to be cleaned twice a day which were every morning after breakfast and night before going to bed. Another effort to maintain oral hygiene was with routine check up to dentist.

Based on questionnaire result, either users or non users of oral contraceptives were lack of awareness in the importance of periodic examination to dentist, $50.72 \%$ users and $43.35 \%$ non users of oral contraceptives went to dentist if they had a tooth ache and $49.28 \%$ users and $56.65 \%$ non users didn't go to dentist.

Based on clinical examination result toward non users of oral contraceptives group as a control group, mean index plaque was 1.787 in moderate category and mean gingival index was 1.707 with severity level of moderate gingivitis. If we compared it with users of oral contraceptives, then the mean gingival index was much higher on users group which was 1.913 with mean plaque index 1.856 , but clinically they had similar severity level which was moderate gingivitis. This result was similar with research that was conducted in Srilanka that showed there was significant difference between gingivitis in users of oral contraceptives and non users. ${ }^{8}$ The research by Pertiwi in Puskesmas Puter also shows a same conclusion that the gingival index on the subjects who take the oral contraceptives was higher than the non oral contraceptives subjects. ${ }^{12}$

The use of oral contraceptives could descend the sturdiness of the gingival tissues, therefore it found to be more susceptible to local iritation and also induced raise the level of gingival inflamation influenced by hormonal factor. Some experts suggested that oral contraceptives could influence the ginggival health of the subjects, it was because almost all of the contraception groups contain steroid progestin derivate..$^{1,8,13}$

The raise of progesterone and estrogen hormone inside the blood flow influences periodontium tissues by modifying its response to plaque as a trigger factor, subsequently it results in periodontal and gingival disease. Moreover, the raise of sexual hormones are also followed by the raise of Provetella bacteria in oral cavity. It also make some oral flora changes on gingival pocket. Dilated blood vein induced by progesterone results in increase of blood vain permeability. Also, it induces the changes in ratio of amount and the model of collagen production so that the decrease of gingival healing and maintenance potence and the increament of destructive metabolism of essential folat for periodontal tissues maintenance and healing occur. Estrogen decreases ceratinization process, in this case the raise of epitelial tissues glicogen occurs and results in lowering the effectiveness of epithelial barrier. ${ }^{3,14,15}$ Estrogen induce the changes in artery and vein, whereas progesterone induce the change in artery. In women who take the oral contraception pills shows some decreament of blood clothing factor in blood plasm influenced by estrogen hormone. . $^{8,14}$

Even the use of oral contraceptivers is not the direct cause of gingivitis but it has some potentials in influencing tissue response to local iritations as a modfying factors. Gingivitis can be minimized through plaque control on the first time of oral contraception pills administration. . $^{8,16}$ 


\section{CONCLUSION}

Based of the experiment results regarding to gingival condition on the sucjects who took the oral contraceptives at Desa Hegarmanah Kecamatan Jatinangor, it could be concluded that the gingival condition on the subjects was categorized as moderate gingivitis and there was a significant difference gingival condition values between users of oral contraceptives and non users of oral contraceptives. Therefore, it was suggested that its essential to promote the importance of oral and dental health to the subjects who take the oral contraceptives, to promote the cooperation between dentist, midwife, midwifery experts, and 'KB' Programme field officer.

\section{REFERENCES}

1. Hoag MP, Pawlak EA. Essentials of periodontic. $4^{\text {th }}$ ed. St. Louis: C.V. Mosby Co.; 1990. p. 1936,39-40.

2. Manson JD, Eley BM. Outline of periodontics. $3^{\text {th }}$ ed. London: Wrigth; 1995. p. 71-3.

3. Newman MG. Takei HH. Klokkevold PR. Carranza's clinical periodontology. $10^{\text {th }}$ ed. Missouri: Saunders Elsevier; 2006. p. 284-307, 636-47.

4. Ganiswarna SG, Setiabudi S, Suyatna FD, Purwantyastuti, Nafrialdi. Farmakologi dan terapi. $4^{\text {th }}$ ed. Jakarta: FK UI; 1995. p. 43955.

5. Rose LF, Terry D, Brian LM. Periodontal medicine. London: B.C. Halminton; 2000.

6. Mariotti A, Preshaw PM, Knutsen MA. Experimental gingivitis in women using oral cotraceptives. 2001. Available from: http:// www.google.com/influence oral contraceptives to gingiva.
7. William JM, Weinberg MA. Periodontal changes in females. US Pharm 2007;32(9):54-6. Available from:http://uspharmacist.com. html.

8. Lindhe J, Karring T. Lang NP. Textbook of clinical periodontology. $4^{\text {th }}$ ed. Oxford: Blackwell Munksgaard; 2003.

9. Harmono Happy. Pengaruh pemberian kontrasepsi oral kombinasi (Etinilestradiol-levonorgestrel) terhadap gambaran mikroskopis gingiva tikus betina jenis Wistar (Rattus norvegiccus). 2003. Available from: http://www.library@ lib.unair.ac.id

10. Bari S. Informasi pelayanan kontrasepsi. Jakarta: BKKBN; 1993.

11. Marwati A. Karakteristik ibu yang mengalami efek samping kontrasepsi hormonal di Puskesmas Medan Sunggal Tahun 2006. Available from: http: / /www. helvetia.co.id. 2008

12. Pertiwi EB. Hubungan pil oral kontrasepsi dengan status kesehatan gingiva (Studi kasus di Puskesmas Puter Bandung). Minor thesis. Bandung: Fakultas Kedokteran Gigi. 1999

13. El Ashiry GM. Effect of oral contraceptive on ginggiva. J Periodontol 1971;42:273-5.

14. Steinberg BJ. Women oral health issues. J Calif Dent Assoc 2004. Available from:http://www. cda.org/member/pubs/journal/jour0900/ women. html.

15. Tozum TF, Guncu GM, Caglayan F. Effects of endogenous sex hormone on the periodontiumreview of literature. Aust Dent J 2005. p. 13845.

16. Zachariasen RO. The effects of elevated ovarian hormones on periodontal health: Oral contraceptives and pregnancy. Women and Health 1993:20;21-30. 